\title{
Life situation of teenage mothers
}

\author{
Agnieszka Bałanda-Bałdyga1,A-D,F, Anna Bogusława Pilewska-Kozak ${ }^{2, C, E}$, Grażyna Stadniska ${ }^{1, E}$, \\ Beata Dobrowolska ${ }^{3, C, E-F}$ \\ ${ }^{1}$ Zakład Podstaw Położnictwa Uniwersytet Medyczny w Lublinie, Polska \\ ${ }^{2}$ Katedra i Klinika Ginekologii i Endokrynologii Ginekologicznej Uniwersytet Medyczny w Lublinie, Polska \\ ${ }^{3}$ Katedra Rozwoju Pielęgniarstwa Uniwersytet Medyczny w Lublinie, Polska \\ A - Koncepcja i projekt badania, B - Gromadzenie i/lub zestawianie danych, C-Analiza i interpretacja danych, D-Napisanie \\ artykułu, E - Krytyczne zrecenzowanie artykułu, F-Zatwierdzenie ostatecznej wersji artykuł
}

Bałanda-Bałdyga A, Pilewska-Kozak AB, Stadniska G, Dobrowolska B. Life situation of teenage mothers. Med Og Nauk Zdr. 2019; 25(3): 138-143. doi: $10.26444 / \mathrm{monz} / 111416$

\begin{abstract}
Introduction. Various factors, i.e. culture, economics, and education, are recognized as being related to the number of juvenile pregnancies worldwide. In Poland, teenage pregnancies account for 3.4-8\% of all pregnancies. Juvenile pregnancy makes a teenage mother change her lifestyle, and motherhood in the period of adolescence influences her further functioning in psychological, social, medical, and legal domains.

Objective. To discover what the life situation of teenage mothers is like, and to establish conditioning factors.

Materials and method. A survey study using an original questionnaire was carried out among 308 teenage mothers, 13-19 years old in eight hospitals in Poland. The study obtained the consent of the Bioethics Committee of the Medical University in Lublin (KE No. 0254/157/2012).

Results. The girls taking part in the study constituted a diverse group in terms of demographic and social characteristics. The youngest group were 13-15-year olds. Over half of the respondents (57.1\%) were rural residents, most (70.8\%) of them unmarried and economically dependent on their parents (88.6\%). The age difference between the child's mother and father was on average four years, and was statistically significant $(p<0.00001)$.

Conclusions. The life situation of teenage mothers must be considered difficult due not only to their young age, but also the necessity to stop school education, lack of work and economic independence, an uncertain future with the child's father, and / or a shortage of social support. There is a need for appropriate education regarding human sexuality, including issues of fertility, emotional relations and responsibility.
\end{abstract}

\section{Key words}

teenage mother, juvenile pregnancy, life situation

\section{INTRODUCTION}

According to the World Health Organization (WHO), an estimated 16 million women aged 15-19 give birth each year, which constitutes about $11 \%$ of all births worldwide. Most of these births (95\%) occur in developing countries. Although data from literature show a decrease in the number of children born to teenage mothers $[1,2]$, the problem is still very much a current issue $[2,3]$.

Teenage mothers often come from families with a history of teenage births - children of teenage parents usually engage early in sexual activity and also become young parents $[2,4$, 5]. There is a kind of inter-generational transmission caused by replication of behavioural patterns by young people who are raised in such a family mode, and treat it as a reference standard [2, 6]. However, reaching sexual maturity is not equivalent to achieving adequate emotional maturity [2, $5,7,8]$

The age of sexual initiation in Poland has decreased significantly over the years. A study conducted in 2006 by Institute of Mother and Child showed that $52.5 \%$ of girls and $61.6 \%$ of boys in post-primary schools had initiated their sexual activity [9], and the project entitled 'Health Behaviour in School-aged Children' revealed that the average age of

Address for correspondence: Agnieszka Bałanda-Bałdyga, Zakład Podstaw Położnictwa Uniwersytet Medyczny w Lublinie, Polska

E-mail: agnieszkabalanda@wp.pl

Received: 04 April 2019; Accepted: 31 July 2019 sexual debut was 14 , and that girls became sexually active slightly later than boys (14.4 vs. 13.6 years of age). Half of the respondents had their first sexual intercourse at the age of 15 , and every third boy and every fourth girl had sexual initiation at the age of $13[2,4]$.

Pregnancy and motherhood begin a new phase in a woman's life. The consequences of juvenile pregnancy have personal as well as social dimension $[2,5,10]$. The economic condition of teenage mothers is determined by the delay in continuing education or achieving a lower educational status, which in future results in limited employment opportunities or even unemployment $[2,11]$. The society in which a young mother and her child live, incurs certain costs, including those related to various benefits and medical care [2]. These days, the social pressure on pregnant teenagers to get married is much lower than several years ago. Nevertheless, the formal establishment of a family is still considered a desirable sequence of events. Marriages concluded because of pregnancy are burdened with a three times higher risk of divorce than in the general population $[2,12]$. Because the model of life propagated and accepted by modern society assumes that gaining education, finding a job, and becoming financially independent should be the priority, and only later, when these are achieved, people should proceed to family planning, pregnant teenagers are treated with disregard, which deprives them of self-esteem [13]. In very young women, pregnancy may also trigger conflicts with those around them, rejection, uncertainty, alienation, surprise, helplessness, and even depression. 


\section{OBJECTIVE}

The aim of the study is to discover what the life situation of teenage mothers is like, and to establish conditioning factors.

\section{MATERIALS AND METHOD}

The survey was carried out in eight selected hospitals in Poland. The study group comprised 308 teenage mothers between the first and the third day postpartum. The inclusion criteria were: age up to 19 years, good general condition at the time of the survey, written informed consent for participation in the study, and in the case of minors, also the consent of their legal guardians. The study was retrospective and participation was voluntary and anonymous. The research method was a diagnostic survey and the research tool an original questionnaire which included single choice and multiple choice closed questions and semi-opened questions. The questions were aimed at collecting information on the age of the respondent and the age of the father of her child, her living and housing conditions, past pregnancies, whether the last pregnancy was planned, preparation for motherhood, and the type of expected help.

Before the survey, the young mothers were instructed how to fill out the questionnaire; in the case of minors, the instructions were also given to their legal guardians. Respondents were given the opportunity to ask for additional explanations and no time limit imposed. Five patients did not give consent to participate in the survey, without giving a reason. Fifteen questionnaires were incomplete and were excluded from this study.

In the study, the subjects were divided into three age groups: $13-15,16-17$ and $18-19$ years of age. This criterion is consistent with the legal status of women which is based on age. In Poland, eighteen and nineteen-year-olds have full legal authority, which means they may enter into marriages without any restrictions. Sixteen and seventeen-year-olds may do so with the consent of the court. Younger women, however, cannot get married, and if they give birth, they cannot disclose the father of the child without the risk of exposing him to criminal sanctions $[14,15,16,17]$. Three terms are used in the study to describe a woman who gave birth to a child before the age of 19: 'young mother', 'teenage mother' and 'teenager'.

The obtained results were subjected to descriptive and statistical analysis. The values of the analyzed parameters measured on a nominal scale were characterized by the number and percentage, and measured on a ratio scale were characterized by the mean value, standard deviation, median, and lower and upper quartile with the range of variability. Contingency tables and homogeneity or independence $\chi^{2}$ tests were used to assess the existence of differences or dependencies between the analyzed non-measurable parameters. For a small data sample in the studied subgroups (below five) the Yates correction was used. A 5\% inference error and the associated materiality level $\mathrm{p}<0.05$, indicating the existence of statistically significant differences or dependencies, were assumed. Statistical analyses were performed using STATISTICA software version 10.0 (StatSoft, Poland).

The research was conducted in accordance with the guidelines of the Helsinki Declaration. The research project was positively assessed by the Bioethics Committee of the Medical University in Lublin (Resolution No. EC 0254/157/2012 of 28 June 2012).

\section{RESULTS}

Table 1 presents information on age ranges, marital status, place of residence, current occupation and main source of income.

Table 1. Socio-demographic data of respondents

\begin{tabular}{|c|c|c|}
\hline Characteristics & \multirow{2}{*}{$\mathrm{N}$} & \multirow{2}{*}{$\%$} \\
\hline Age ranges (in years) & & \\
\hline $13-15$ & 7 & 2.3 \\
\hline $16-17$ & 79 & 25.6 \\
\hline $18-19$ & 222 & 72.1 \\
\hline Marital status & $\mathrm{N}$ & $\%$ \\
\hline Unmarried - single & 66 & 21.4 \\
\hline Unmarried - in partnership & 152 & 49.4 \\
\hline Married & 90 & 29.2 \\
\hline Place of residence & $\mathrm{N}$ & $\%$ \\
\hline Big city & 50 & 16.2 \\
\hline Small city & 82 & 26.7 \\
\hline Village & 176 & 57.1 \\
\hline Current occupation & $\mathrm{N}$ & $\%$ \\
\hline Learning & 207 & 67.2 \\
\hline Working & 23 & 7.5 \\
\hline Not learning and not working & 78 & 25.3 \\
\hline Main source of income & $\mathrm{N}$ & $\%$ \\
\hline Parents & 137 & 44.5 \\
\hline Father of the child & 136 & 44.1 \\
\hline Work & 19 & 6.2 \\
\hline Benefits and child maintenance & 16 & 5.2 \\
\hline
\end{tabular}

The age of the respondents ranged from 13 to 19 years, with an average of $18.1\left(\mathrm{Me} 19 ; \mathrm{Q}_{1} 17 ; \mathrm{Q}_{3} 19\right)$. The youngest age group (up to 15 years of age) counted seven (2.3\%) women, the medium age group (16-17 years of age) comprised 79 (25.6\%) women, and in the oldest group (18-19 years of age) there were $222(72.1 \%)$ women. 152 (49.4\%) respondents were in common-law partnership with the father of the child, 90 (29.2\%) were married, and 66 (21.4\%) were single mothers. Over half of the respondents were rural residents (176; 57.1\%) and the remaining $132(42.9 \%)$ teenagers lived in cities. In this group, $82(26.7 \%)$ lived in cities with a population under 200,000 inhabitants, and 50 (16.2\%) lived in cities with a population over 200,000 inhabitants. Most of them attended schools (207; 67.2\%), 23 (7.5\%) worked and 78 (25.3\%) did neither. At the time of the survey, most respondents were financially dependent on their parents $(137 ; 44.5 \%)$ or on the father of the child and his family (136; 44.1\%), 19 (6.2\%) were self-sufficient, and for the remaining 16 (5.2\%) women, the source of income was unemployment benefit, child maintenance or a social assistance benefit from a municipal social welfare centre.

Most girls attended general secondary schools (87; 42.0\%), 40 (19.3\%) studied at technical secondary schools; 32 (15.5\%) were in vocational schools; 29 (14.0\%) were learning in junior 
high schools and two (1.0\%) in primary schools. Among the respondents there were also $17(8.2 \%)$ university students. Nearly half of all school-goers $(94 ; 45.4 \%)$ discontinued their education after they discovered they were pregnant. After giving birth, most of them $(191 ; 92.3 \%)$ intended to return to school. The remaining $16(7.7 \%)$ declared that they did not intend doing so.

The age of the father ranged from 16 to 36 years with an average of $22.2\left(\mathrm{Me} 21 ; \mathrm{Q}_{1} 20 ; \mathrm{Q}_{3} 24\right)$. It has to be mentioned that three mothers did not know the age of the father of their child. The average age difference between the mother and the father was 4.0 years $\left(\mathrm{Me} 3 ; \mathrm{Q}_{1} 2 ; \mathrm{Q}_{3} 6\right)$ and was statistically significant $(\mathrm{p}<0.00001)$ for fathers. In $116(37.7 \%)$ cases, the mother and the father were of the same age. In 109 cases, the father was one to five years older than the mother, and in 80 (25.9\%) situations he was more than five years older than the mother. 45 (14.6\%) young mothers had no siblings and the remaining $263(85.4 \%)$ had brothers or sisters. In this group, more than half of the respondents $(172 ; 55.8 \%)$ had older siblings, and the rest had siblings of the same age or younger.

During pregnancy, $240(78.0 \%)$ teenage girls lived with their parents and/or siblings, 58 (18.8\%) lived with the child's father or with him and his parents, 10 (3.2\%) lived alone. After the birth of the child, 108 (35.1\%) young mothers declared that they would live with their parents, 193 (62.7\%) stated that they would live with the child's father or with him and his parents, and seven $(2.2 \%)$ were to live alone. The differences between the place of residence of the respondents during the pregnancy and after the childbirth are presented in Table 2.

Table 2. Place of residence during the pregnancy and after childbirth

\begin{tabular}{lcccc}
\hline \multirow{2}{*}{ Place of residence } & \multicolumn{2}{c}{ During pregnancy } & \multicolumn{2}{c}{ After childbirth } \\
\cline { 2 - 5 } & $\mathrm{n}$ & $\%$ & $\mathrm{~N}$ & $\%$ \\
\hline With parents & 240 & 77.9 & 108 & 35.1 \\
\hline With the father of the child & 58 & 18.9 & 193 & 62.7 \\
\hline Alone & 10 & 3.2 & 7 & 2.2 \\
\hline Materiality & \multicolumn{3}{c}{$\mathrm{X}^{2}=107.36 ; \mathrm{p}<0.00001$} & \\
\hline
\end{tabular}

The place of residence of the respondents during the pregnancy and after the childbirth differed significantly $(\mathrm{p}<0.00001)$. The difference concerned the shift from living with the parents to living with the father of the child, and this option after the childbirth increased more than three times (from $18.9 \%$ to $62.7 \%$ ).

Most respondents $(243 ; 78.9 \%)$ were planning their future together with the father of the child, 44 (14.3\%) young mothers were not able to determine their plans at that time, while the remaining $21(6.8 \%)$ had no such plans at all. It has to be mentioned that the length of time for which the respondents had known the child's father prior to getting pregnant ranged from one month to eight years, on average 24 months (Me 20; $\left.Q_{1} 11 ; Q_{3} 36\right)$.

Obstetric history. For 275 (89.3\%) respondents this was their first pregnancy, for 28 (9.1\%), the second pregnancy, and the remaining five $(1.6 \%)$ girls had been pregnant two or more times before. 211 (68.5\%) respondents claimed that the pregnancy was not planned. The other 97 (31.5\%) declared that they had planned the pregnancy. 222 (72.1\%) respondents confirmed that they had controlled their fertility. The remaining 86 (27.9\%) denied this and the most frequent motivation they provided was the lack of knowledge in this area $(35 ; 11.4 \%)$ or the lack of such need $(20 ; 6.5 \%) .17$ (5.5\%) young mothers thought they would not get pregnant, nine (2.9\%) intended to use contraception in the future, while five (1.6\%) feared that their parents might notice that they were using birth control.

Among the teenagers who made any effort to control their fertility, the majority $(106 ; 34.4 \%)$ used a condom, 37 (12.0\%) used natural family planning methods, 33 (10.7\%) used interrupted sexual intercourses (coitus interruptus), and 17 (5.5\%) took contraceptive pills. Dual protection in the form of condoms and contraceptive pills was used by seven $(2.3 \%)$ teenagers, and condoms together with interrupted sexual intercourses were used by $22(7.2 \%)$ respondents.

The last pregnancy. Most respondents (185; 60.1\%) discovered they were pregnant just one month after the menstrual period stopped, $79(25.6 \%)$ teenagers realized they were pregnant after two months, 28 (9.1\%) after three, and 16 (5.2\%) after four months, or even later.

The relationship between the time elapsed between the absence of menstruation and finding out about the pregnancy and the respondents' age and place of living is shown in Table 3.

Table 3. Lapse of time between absence of menstruation and finding out about the pregnancy and respondents' age and place of ressidence.

Lapse of time between

absence of menstruation and finding out about pregnancy

\begin{tabular}{|c|c|c|c|c|c|c|c|c|}
\hline & & & & & & & & \\
\hline \multirow[t]{2}{*}{ Characteristics } & \multicolumn{2}{|c|}{1 month } & \multicolumn{2}{|c|}{2 months } & \multicolumn{2}{|c|}{3 months } & \multicolumn{2}{|c|}{$\begin{array}{l}4 \text { months } \\
\text { or longer }\end{array}$} \\
\hline & \multicolumn{2}{|c|}{$\mathrm{n}=185 ; 60.1 \%$} & \multicolumn{2}{|c|}{$n=79 ; 25.6 \%$} & \multicolumn{2}{|c|}{$n=28 ; 9.1 \%$} & \multicolumn{2}{|c|}{$n=16 ; 5.2 \%$} \\
\hline Age & $\mathrm{N}$ & $\%$ & $\mathrm{~N}$ & $\%$ & $\mathrm{~N}$ & $\%$ & $\mathrm{~N}$ & $\%$ \\
\hline $13-15$ & 2 & 1.1 & 2 & 2.5 & 2 & 7.1 & 1 & 6.2 \\
\hline $16-17$ & 41 & 22.1 & 19 & 24.1 & 12 & 42.9 & 7 & 43.8 \\
\hline $18-19$ & 142 & 76.8 & 58 & 73.4 & 14 & 50.0 & 8 & 50.0 \\
\hline Materiality & \multicolumn{8}{|c|}{$X^{2}=15.00 ; p=0.02$} \\
\hline Place of residence & $\mathrm{N}$ & $\%$ & $\mathrm{n}$ & $\%$ & $\mathrm{n}$ & $\%$ & $\mathrm{~N}$ & $\%$ \\
\hline Big city & 25 & 13.5 & 14 & 17.7 & 8 & 28.6 & 3 & 18.7 \\
\hline Small city & 51 & 27.6 & 23 & 29.1 & 6 & 21.4 & 2 & 12.5 \\
\hline Village & 109 & 58.9 & 42 & 53.2 & 14 & 50.0 & 11 & 68.7 \\
\hline Materiality & \multicolumn{8}{|c|}{$X^{2}=6.32 ; p=0.39$} \\
\hline
\end{tabular}

The time elapsed between the absence of menstruation and finding out about the pregnancy was significantly related to the respondents' age $(\mathrm{p}=0.02)$. However, there was no such relation to their place of residence $(\mathrm{p}=0.39)$.

\section{DISCUSSION}

Girls who took part in the study constituted a diverse group in terms of several demographic and social characteristics. Their age ranged from 13-19 years, but the average for this range was high (18.1 years). This was due to the fact that women who gave birth at the age 18-19 constituted the biggest group of respondents (72.1\%). According to the reports of Mangeli et al. [18], 19-year-olds give birth to about half of the children born by teenage mothers. According to the World Bank [19], in Poland the number of pregnancies among girls aged 15-19 
is decreasing. Szukalski $[1,20]$ made an observation based on the analysis of Demographic Yearbooks from the last 40 years, that the incidence of pregnancies among teenagers has decreased (a 59.4\% decrease between 1970-2009). However. since 2005, there has been a slow increase in the number of births by teenagers, with an even faster rate of increase in fertility among women aged under 17 [1,20,21]. A similar trend is observed in more developed countries [21,22].

In the presented study, girls up to the age of 15 were the youngest and the smallest group of respondents (2.3\%). From the legal point of view, they were persons against whom a criminal offence has been committed by causing them to engage in sexual activities $[5,8,14,15,16,17]$. Polish law treats sexual intercourse with a minor differently from the Federal Penal Code of the United States, which provides that sexual relations with children between the ages of 12 and 16 are punishable if the person is four or more years older than the minor [23].

More than a half of the respondents (57.1\%) were girls living in rural areas. As observed by Kagawa et al. [22], teenage motherhood is a more frequent phenomenon in poorer regions, to which rural areas undoubtedly belong. Szukalski [24], on the other hand, presents an opposite view. In any case, it seems that in order to better determine the scale of this phenomenon, research is needed to assess its occurrence in a representative rural and urban population. Taking into account the size of the population concentrations, the differences may prove to be small.

Marital status of the respondents varied; however, unmarried girls prevailed (70.8\%), although it is worth noting that there were more than twice as many unmarried women living in cohabitation with the father of their child, than unmarried single mothers. This situation can be regarded as a relatively good prognosis for the child to be raised in a complete, two-parent family. This assumption can also be supported by the declarations made by the majority of the respondents (78.9\%) concerning their plans for future, together with the father of the child. Obviously it is not known whether such a scenario will actually take place. According to the report 'Teenage motherhood and marriage' from 2003, nearly one-third of teenage mothers claim that they will 'definitely' marry the biological father of their child, and $23 \%$ definitely deny such a possibility. In reality, only less than $8 \%$ of teenage mothers marry the father of their child within one year after giving birth. Moreover, early motherhood will often reduce the chance of these girls of ever getting married, and increases the risk of single motherhood [8]. The reasons for teenage mothers ending up alone can be found, among others, in a rather short and accidental acquaintance with the father of the child, as confirmed by a study conducted by Pieskowa among 180 single mothers. Men who became the fathers of their children were almost unknown to the surveyed women. $17.8 \%$ of the mothers took no interest in their partner's education, profession, marital status and workplace. When they were informed about the pregnancy, these men usually abandoned their pregnant partners [25].

Most respondents who took part in the presented study attended schools, mostly secondary schools (61.3\%), 42.0\% of them went to general secondary schools and $19.3 \%$ to technical secondary schools. Similar results were obtained by Bakiera and Szczerbal [5] - 50.4\% of their respondents attended secondary schools. The results concerning further educational aspirations of teenagers seem optimistic - after giving birth the prevailing majority of respondents (92.5\%) intended to continue with their education. The study by Królikowska [3] showed that $84.7 \%$ of respondents actually did return to school; however, in the research by Ekonjo et al. [26], only $39.8 \%$ did so.

At the time of the current study, the vast majority of the teenage mothers $(88.6 \%)$ were financially dependent on their parents or on the father of the child and his family. Only a few actually worked. A similar tendency was reported by other authors [26]. Taking into account their age this seems completely understandable.

In the presented study, the age difference between the mother and the father of the child was four years, on average, and was statistically significant $(\mathrm{p}<0.00001)$ for fathers. Only three $(1.0 \%)$ mothers did not know the age of their child's father, $61.3 \%$ of the fathers were older than the mothers and $37.7 \%$ were of the same age or younger. Szukalski $[20,27]$ shows different statistics $-30.1 \%$ of his respondents could not or did not want to specify the age of their child's father. This indicates a weak bond between teenage mothers and the fathers, many of whom will probably not go beyond the stage of biological fatherhood. The study conducted by Mangeli et al. [28] reveals that the fathers of children born to teenage mothers are usually aged over 20, most often between 20-24 years of age. Younger fathers constituted only slightly over $8 \%$. In the study by Królikowska [3], the fathers were also usually older than their partners. although more than half of them were between 18-21 years of age. and about 30\% were between 22-24. Izdebski et al. [29] presented results showing that a father of a child born by a teenage mother was more often than not aged $20-24$ (59.8\%), while their peers constituted $13.2 \%$. Not infrequently, men were much older than their partners - in $5.6 \%$ of cases they were 30 -years-old or older, some of them were even over 50 years of age.

Conception planning, prenatal period and birth. For the majority of the teenage girls who took part in the study (89.3\%), their pregnancy was first and most often unplanned (68.5\%). It is disturbing to find that for $10.7 \%$ of such young girls, the pregnancy was the second or even the third pregnancy. Taking into account the average length of acquaintance with the child's father ( 24 months), it can be concluded that these pregnancies were most often not the result of accidental sexual contacts. On the basis of the collected material, it is not possible to give an unambiguous answer to why these pregnancies happened. In a study by Rycel et al. [30], the proportion of multipara was much smaller (3.9\%). Some authors claim that more than a half of teenage mothers become pregnant again within two years of the first pregnancy. The reasons for this are: the still young age of the mother, low level of education of both the mother and her partner, forced marriage (because of the first pregnancy), and use of ineffective contraception $[9,26,30,31]$.

Analysis of the research material shows that almost every third respondent planned to conceive a child, and those who did so were mainly married women (29.2\%). However, one may have some doubts about the reliability of these declarations. It is difficult to believe that teenagers wanted and made conscious efforts to have one, two or even three children at such a young age. This conclusion can be inferred, among others, from the fact that getting pregnant at this age made it necessary for the respondents to stop school 
education, the future with the child's father was uncertain, and the socio-economic status of the respondents was low.

Another area that was surveyed was the control of fertility which was declared by $72.1 \%$ of the respondents. It has to be mentioned that it was often a condom used by the partner. Only few teenagers used more effective contraception. In Germany in recent years, there has been a significant increase in the use of hormonal contraception among adolescent girls [32], and in the United States the use of contraception by adolescents appears to be quite common [33]. According to the current WHO recommendations, teenagers and young women should use dual protection and dual method in the form of a highly effective contraceptive combined with a condom. The aim is to protect oneself against unplanned pregnancy and sexually transmitted infections. The results of this study show that only $2.3 \%$ of girls used dual protection in compliance with the WHO recommendations - that they used condoms and contraceptive pills.

A major problem with the use of contraception by teenagers is its lower effectiveness (up to 10 times lower) arising from the mistakes they make when using it [34] and problems with access. the Seminar of the European Society of Contraception (ESC) in Coimbra, Portugal, in 2001, the question of whether parents should be asked for consent to the prescription and use of contraceptives by adolescents was discussed. Most participants shared the view that as long as a teenager does not have to ask (and does not ask) for parental consent to have sexual intercourse, parents' consent to prescribe contraceptives to their children should also not be required [35]. In Poland, this issue was raised by SowińskaPrzepiera and Jarząbek-Bielecka [17], who proposed rules of conduct in paediatric and girls' gynaecology clinics with regard to underage patients who are sexually active. To-date, there has been no clear position of the medical and legal communities on the procedures of dealing with such a girl who requests a prescription for contraceptive pills. In making such decisions, one should be aware that there is an absolute requirement for a co-decision on this matter by the parent or the statutory representative of a minor $[17,23,36]$. It should also be remembered that half of the unplanned pregnancies in teenagers result from the lack of contraception, and the other half from its low effectiveness [37].

Most of the respondents realized that they were pregnant in the first trimester, and even one month after menstruation stopped. The length of time elapsed between the absence of menstruation and finding out about the pregnancy was significantly related to the respondents' age $(\mathrm{p}=0.02)$. It is known from the literature that a woman's age at the time of becoming pregnant has an influence on the quality of the events related to this fact - from the first reaction of the pregnant woman, of the father of the child and of her parents, to the relations with her immediate environment. All former issues, life plans or interests of a pregnant teenager change, and the issues related to the pregnancy, childbirth, child care and the future, and all related concerns come to the fore $[8,38]$.

\section{CONCLUSIONS}

The life situation of teenage mothers must be regarded as difficult, not only because of their young age (average age of respondents was 18), but also because of the necessity to leave school (nearly a half of respondents discontinued education after they discovered they were pregnant), lack of work and economic independence (the majority of respondents were financially dependent on others), uncertainty about the future with the father of the child and/or a lack of social support (most of respondents were planning their future together with the father of the child). There is a need for appropriate education regarding human sexuality, including issues of fertility, emotional relations and responsibility.

\section{REFERENCES}

1.Szukalski P. Childbirths of teenagers. [Urodzenia nastolatek] Demografia i Gerontologia Społeczna - Biuletyn Informacyjny. 2016; 6: $1-4$.

2. Kielan A. Cieślak I. Opinion of Internet users about underage pregnancies. [Opinia internautów na temat ciąż nieletnich]. Dziecko Krzywdzone. Teoria. Badania. Praktyka. 2016; 15(4): 23-43.

3. Królikowska S. Social situation of teenage mothers. [Sytuacja społeczna młodocianych matek]. Dysfunkcje rodziny. W: Kotlarska-Michalska A. red. Roczniki Socjologii Rodziny. Studia socjologiczne oraz interdyscyplinarne. Wydawnictwo Naukowe UAM. Poznań; 2011. p. 79-101.

4. Woynarowska. B. Sexual behawior of 15-year-old youth. [Zachowania seksualne młodzieży 15-letniej]. In: Mazur J. ed. Health and health behavior of school youth in Poland in the background of selected sociodemographic conditions. Results of research of HBSC 2014. [Zdrowie i zachowania zdrowotne młodzieży szkolnej w Polsce na tle wybranych uwarunkowań socjodemograficznych. Wyniki badań HBSC 2014]. Instytut Matki i Dziecka. Warszawa; 2015.

5. Bakiera L. Szczerbal J. The teenage motherhood experience and selected aspects of the adult women functioning. [Doświadczenie nastoletniego macierzyństwa a wybrane aspekty funkcjonowania dorosłych kobiet]. Polskie Forum Psychologiczne. 2018; 23(1): 102-121.

6. Padała O. Podgórniak M. Sadowska M. Adolescent maternity as a medical and social problem. [Młodociane macierzyństwo jako problem medyczny i społeczny]. Eur J Med Technol. 2014; 2(3): 61-65.

7. Żelazkowska M. Shaping the image of motherhood by an adolescent mother. Socio-psychological perspecive. [Kształtowanie obrazu macierzyństwa przez nastoletnie matki. Perspektywa społecznopsychologiczna] Społeczeństwo. Edukacja. Język 2016; 4: 63-72.

8. Kempińska U. Minor motherhood - a global problem. [Nieletnie macierzyństwo - problem ogólnoświatowy]. Instytut NaukowoWydawniczy MAIUSULA sp. zo.o. Poznań 2017.

9. Pawłowska A. Filipp E. Pietrasik D. Krawczyńska M. Wilczyńska A. Niemiec KT. Analysis of the course of pregnancy and obstetric results in adolescent girls giving birth in the Obstetrics and Gynecology Clinic of the Mother and Child Institute in Warsaw. [Analiza przebiegu ciąży oraz wyników położniczych u nastolatek rodzących w Klinice Położnictwa i Ginekologii Instytutu Matki i Dziecka w Warszawie]. Ginekol Prakt. 2005; 84: 41-45.

10. Włodarczyk E. Teenage motherhood as an individual and social problem [Nastoletnie macierzyństwo jako problem indywidualny i społeczny]. In: Marzec-Holka K. ed. Social capital and inequalities - accumulation and redistribution [Kapitał społeczny a nierówności - kumulacja i redystrybucja]. Wydawnictwo Uniwersytetu Kazimierza Wielkiego. Bydgoszcz: 2009. p. 454-463.

11. Fraser AM. Association of young maternal age with adverse reproductive outcomes. N Engl J Med. 1995; 17(332): 1113-1117. https://doi/10.1056/ NEJM199504273321701.

12. Pankrac Z. Świątkowska-Freud M. Preis K. Lautenbach D. Analysis of the social situation and its impact on the course of pregnancy and delivery in juvenile pregnant women hospitalized at the Institute of Obstetrics and Women >s Diseases of the Medical Academy in Gdańsk in the years 1985-1986 and 1995-1996 [Analiza sytuacji społecznej i jej wpływ na przebieg ciąży i porodu u młodocianych ciężarnych hospitalizowanych w Instytucie Położnictwa i Chorób Kobiecych Akademii Medycznej w Gdańsku w latach 1985-1986 i 1995-1996]. Ann UMCS Sect D Med. 59 suppl. 2004; 14(4): 295-297.

13. Frankowicz-Gasiul B. Michalik A. Czerwińska A. Zydorek M. Olszewska J. Olszewski J. Adolescent pregnancy - medical and social problem. [Ciąża młodocianych - problem medyczny i społeczny]. Stud Med. 2008; 11: 57-63. 
14. Krajewski R. Juvenile marriage in the light of law. [Małżeństwo małoletniej w świetle prawa]. Probl Opiek Wychow. 2008; 3: 44-49.

15. Krajewski R. Legal aspects of juvenile pregnancy [Prawne aspekty ciąży małoletniej]. Probl Opiek Wychow. 2010; 3: 44-50.

16. Krajewski R. Criminal aspects of consensual sexual activity of juveniles [Prawno karne aspekty dobrowolnej aktywności seksualnej małoletnich]. Prokur Prawo. 2012; 10: 5-25.

17. Sowińska-Przepiera E. Jarząbek-Bielecka G. Andrysiak-Mamos E. Syrenicz A. Friebe Z. Kędzia W i wsp. Legal aspects in pediatric and adolescent gynecology. [Wybrane aspekty prawne w ginekologii wieku rozwojowego]. Ginekol Pol. 2013; 84(2): 131-136.

18. Mangeli M. Rayyani M. Cheraghi MA. Tirgari B. Exploring the challenges of adolescent mothers from their life experiences in the transition to motherhood: a qualitative study. J Fam Reprod Health 2017; 11: 165-173.

19. World Bank. Adolescent fertility rate (births per 1000 women ages 15-19). Retrived od; 2016. http://data.worldbank.org/indicator/SP.ADO. TFRT (dostęp: 23.05.2019)

20. Szukalski P. Teenage motherhood in contemporary Poland. [Nastoletnie macierzyństwo we współczesnej Polsce]. Polityka Społ. 2011; 1: 14-18.

21. Skowrońska-Pućka A. Educational situation of minors mothers pupil childcare centers. biographical perspective. [Sytuacja edukacyjna małoletnich matek. wychowanek placówek opiekuńczowychowawczych. Perspektywa biograficzna]. Studia Edukacyjne. 2016; 40: 191-211.

22. Kagawa R. Deardorff J. Domínguez Esponda R. Craig D. Fernald LC. The Experience of Adolescent Motherhood: An Exploratory Mixed Methods Study. J Adv Nurs. 2017; 73: 2566-76. https://doi:10.1111 / jan.13329.

23. Jarząbek-Bielecka G. Durda M. Sowińska-Przepiera E. Kaczmarek M. Kędzia W. Sexual activity among young women. Medical and legal aspects. [Aktywność seksualna dziewcząt. Aspekty medyczne i prawne]. Ginekol Pol. 2012; 83(11): 827-834.

24. Szukalski P. Extra-marital births in Poland - the problem of social policy [Urodzenia pozamałżeńskie w Polsce - problem polityki społecznej]. Prob Polityk Społ Stud Dyskusje. 2003; 5: 94-98.

25. Landwójtowicz P. Single motherhood. [Samotne macierzyństwo]. Studium pastoralne. Redakcja Wydawnictw Wydziału Teologicznego Uniwersytetu Opolskiego. Opole. 2004.

26. Ekonjo GB. Pałczyński B. Gryboś M. Pregnancy and childbirth in juveniles as social and health problem [Ciąża i poród u młodocianych jako problem społeczny i zdrowotny]. Ginekol Prakt. 2003; 11(6): 47-52.
27. Szukalski P. Extra-marital births in Poland at the turn of the 20th and 21st centuries [Urodzenia pozamałżeńskie w Polsce na przełomie XX i XXI wieku]. Wiad Statyst. 2010; 2: 38-52.

28. Izdebski Z. Niemiec T. Wąż K. (Too) young parents. [(Zbyt) młodzi rodzice]. TRIO. Warszawa. 2011.

29. Rycel M. Wilczyński J. Sobala W. Nowakowska D. Analysis of teenage pregnancy outcome and delivery between 2000 and 2006. [Analiza przebiegu ciąży i porodu u nastolatek w latach 2000-2006]. Ginekol Pol. 2008; 79(12): 867-870.

30. Olejek A. Binkiewicz P. Nowak L. Chimiczewski P. Course of pregnancy and delivery in adolescents aged 14-18 in I Clinical Unit of Obstetrics and Gynecology in Bytom (1997-2001). [Analiza przebiegu ciąży i porodów u pacjentek w wieku 14-18 lat rodzących w Katedrze i Oddziale Klinicznym Położnictwa i Ginekologii w Bytomiu w latach 1997-2001]. Ginekol Pol. 2003; 74(8): 603-605.

31.Ziller M. Rashed AN. Ziller V. Kostev K. The prescribing of contraceptives for adolescents in German gynecologic practices in 2007 and 2011: a retrospective database analysis. J Pediatr Adolesc Gynecol. 2013; 26(5): 261-264. https://doi.org/10.1016/j.jpag.2013.04.003

32. Rocca CH. Harper CC. Raine-Bennett TR. Young Women's Perceptions of the Benefits Of Childbearing: Associations with Contraceptive Use and Pregnancy. Perspect Sex Reprod Health. 2013; 45(1): 23-31. https:// doi.org/10.1363/4502313.

33. Skrzypulec-Plinta V. Drosdzol-Cop A. Contraception in adolescents. [Antykoncepcja u młodocianych]. Perinatol Neonatol Ginekol. 2012; 5(2): 96-99.

34. Lech MM. Pregnancy and parenthood prevention in juveniles. [Zapobieganie ciąży i rodzicielstwu u młodocianych]. Zdr Publ. 2002; 112(3): 420-421.

35. Recommendations of the experts' group of the Polish Gynaecological Society regarding gynaecological examination and treatment of the juvenile person elaborated on January 26 2009. [Rekomendacje grupy ekspertów Polskiego Towarzystwa Ginekologicznego dotyczące badania ginekologicznego i leczenia osoby nieletniej opracowane w dniu 26 stycznia 2009 roku]. Ginekol Pol. 2009; 80(3): 218-219.

36. Jakimiuk AJ. Nowicka M. Contraception of juveniles. [Antykoncepcja młodocianych]. Ginekol Dypl. 2007; 9(4): 28-41.

37. Biesiada L. Krajewski P. Jaworska-Pietraszek J. Pietrzak Z. Krasomski G. The course of pregnancy and childbirth in juvenile mothers [Przebieg ciąży i porodu u pacjentek młodocianych]. Klin Perinatol Ginekol. 2007; 43(2): 66-68.

\title{
Sytuacja życiowa nastoletnich matek
}

\author{
I Streszczenie \\ Wprowadzenie. Liczba nastoletnich matek na świecie uzależniona jest od uwarunkowań kulturowych, ekonomicznych oraz \\ edukacyjnych. W Polsce ciąże u nastolatek stanowią 3,4-8\% wszystkich ciąż. Fakt zajścia w ciążę przez tak młodą kobietę \\ wymusza na niej zmianę dotychczasowego stylu życia, a zostanie matką w okresie adolescencji wywiera wpływ na dalsze \\ jej funkcjonowanie w wymiarze psychologicznym, społecznym, medycznym i prawnym. \\ Cel pracy. Sprawdzenie, jaka jest sytuacja życiowa nastoletnich matek i czym jest ona uwarunkowana. \\ Metoda. Badania sondażowe przy użyciu autorskiego kwestionariusza ankiety. Objęto nimi 308 nastoletnich matek w wie- \\ ku od 13. do 19. roku życia. Przeprowadzono je w 8 szpitalach w Polsce. Na badania uzyskano zgodę Komisji Bioetycznej \\ Uniwersytetu Medycznego w Lublinie nr KE 0254/157/2012. \\ Wyniki badań. Dziewczęta biorące udział w badaniach stanowiły zróżnicowaną grupę pod względem kilku cech demogra- \\ ficznych i społecznych. Najmłodszą grupę stanowiły dziewczęta od 13. do 15. roku życia. Ponad połowa badanych (57,1\%) \\ to mieszkanki wsi, w większości (70,8\%) panny, pozostające na utrzymaniu rodziców (88,6\%). Różnica wieku między matką \\ a ojcem dziecka wynosiła średnio 4 lata i była statystycznie znamienna $(p<0,00001)$. \\ Wnioski. Sytuację życiową nastoletnich matek trzeba uznać za trudną nie tylko z powodu ich młodego wieku. Także \\ z powodu konieczności przerwania nauki w szkole, braku pracy, braku niezależności ekonomicznej i niepewności co do \\ wspólnej przyszłości z ojcem dziecka. Istnieje potrzeba właściwej edukacji na temat ludzkiej seksualności, włączając w to \\ zagadnienia dotyczące płodności, relacji emocjonalnych oraz odpowiedzialności.
}

\section{Słowa kluczowe}

przedwczesne macierzyństwo, nastolatka w ciąży, sytuacja życiowa 